\title{
Implant placement simultaneously sinus augmentation using crestal approach in severely atrophic maxilla; minimally invasive approach
}

\author{
Hyun-Joo Kim, Eun-Young Kwon, Jeomil Choi, Ju-Youn Lee, Ji-Young Joo* \\ Department of Periodontology, School of Dentistry, Pusan National University, Yangsan, Republic of Korea
}

The atrophy of edentulous ridge and pneumatization of the maxillary sinus often limit the volume of bone available for implant placement on maxillary posterior teeth. Most clinicians suffer difficulties from poor bone quality and quantity on maxillary posterior site. Thus, the success of maxillary posterior implant surgery depends on the increase of the available bone and obtaining a good initial stability of the implant after maxillary sinus reconstruction. The maxillary sinus augmentation methods include a crestal approach and a lateral approach. Less morbidity and complications after operation is major advantage to sinus augmentation using crestal approach than lateral approach. However, when the residual ridge height is $\geq 6 \mathrm{~mm}$, it is known that crestal approach is appropriate. Also delayed implantation after sinus augmentation is recommended in severely atrophic ridge. We present the three cases of implant placement simultaneously sinus augmentation using crestal approach in posterior maxilla site with $\leq 3 \mathrm{~mm}$ of residual alveolar bone. (J Dent Rehabil Appl Sci 2017;33(1):47-54)

Key words: dental implants; maxillary sinus; alveolar bone grafting; molar

\section{서론}

상악 구치부는 가용골 부족과 나쁜 골질로 인해 하악 구치부에 비해서 임상가들이 임플란트 수술시 어려움을 겪는 경우가 많다. 따라서 상악 구치부 임플란트 수술의 성공은 상악동저의 거상 후 가용골의 증대와 취약한 골 에서 임플란트의 견고한 초기 고정을 획득하는 방법에 달려있다.

수직적 치조제 흡수와 상악동 함기화로 위축된 상악 구치부의 해부학적 한계를 극복하기 위하여 임플란트 시 술시 상악동 골이식술을 동반하는 경우가 많다. 상악동 골이식술을 통해 상악 구치부의 수직적인 골양과 골질을 증강시켜 적절한 길이의 임플란트 식립을 가능하게 한 다. 상악동 골이식술은 치조정 접근법과 측방 접근법이

*Correspondence to: Ji-Young Joo

Assistant Professor, Department of Periodontology, School of Dentistry, Pusan National University, 20 Geumo-ro, Beomeo-ri, Mulguem-eup, Yangsan, 50612, Republic of Korea

Tel: +82-55-360-5203, Fax: +82-55-360-5194, E-mail: joojy@pusan.ac.kr

Received: January 20, 2017/Last Revision: February 14, 2017/Accepted: February 26, 2017
있으며, 치조정 접근법이 좀더 보존적인 술식으로 측방접 근법에 비해 짧은 수술 시간과 최소한의 판막절개, 상악 동 천공이나 술후 부종 및 감염의 위험성을 최소화 할 수 있는 장점을 가지는 것으로 알려져 있다. ${ }^{1}$

치조정 접근법의 상악동 골이식술은 덜 침습적인 술식 이라는 장점이 있지만 일반적으로 잔존골 높이가 $6 \mathrm{~mm}$ 이상에서 추천되고 4-5mm 가량의 상악동저 거상 및 가용골 증대를 야기할 수 있다고 알려져 있다. ${ }^{2}$ 전통적인 치조정 접근법은 수직 방향으로만 상악동저 거상이 이루 어 지는 개념으로 많은 양의 상악동저 거상시 장력이 발 생해 상악동막 천공 위험이 높아져서 1 회에 상악동 골이 식량의 한계를 가지므로 수직적 잔존골 높이가 $5 \mathrm{~mm}$ 이 하일 때는 측방접근법이나 2회의 치조정 접근법이 추천 되었다. 최근 Cochrane systematic review에 따르면 잔존

Copyright (C) 2017 The Korean Academy of Stomatognathic Function and Occlusion. (c) It is identical to Creative Commons Non-Commercial License. 
치조제의 높이가 3-6 mm라면 치조정 접근법으로 상악 동저를 거상하고 $8 \mathrm{~mm}$ 길이의 임플란트를 식립하는 것 이 최소 $10 \mathrm{~mm}$ 이상의 임플란트를 식립하기 위해 측방 접근법을 시행하는 것보다 합병증이 적고 덜 침습적인 방법이라 추천된다고 하였지만 이러한 방법에 관해서는 짧은 임플란트와 치관-치근 비율과 관련하여 여전히 임 플란트 성공율과 생존율에 관해서 논쟁이 있다. ${ }^{3,4}$

본 연구에서는 수직적 잔존골 높이가 $3 \mathrm{~mm}$ 이하인 심 하게 위축된 상악 구치부에서 치조정 접근법을 이용하여 상악동 골이식술을 시행함과 동시에 $13 \mathrm{~mm}$ 길이의 임플 란트를 식립한 후 최종 보철장착 1 - 2년된 세 증례를 통 해 수직 골 소실이 심한 상악 구치부에서 최소침습적 수 술법으로 치조정 접근을 통한 상악동 골이식과 동시에 임플란트 식립을 시행하여 합병증 없이 충분한 길이의 임 플란트 식립이 가능함을 제안한다.

\section{증례보고}

\section{증례 1}

상악 좌측 제1대구치(\#26)의 저작시 통증을 주소로 내 원한 50 세 남성 환자이다. 치근단부까지 치조골 소실이 진행된 상태로(Fig. 1A), 2도의 치아동요도 및 화농성 삼 출물이 치은 열구에서 배출되어 가망 없음으로 진단 후 발치하였다. 환자는 하루에 한 갑의 담배를 피우는 흡연 자로 임플란트 시술 전 금연치료를 선행하였다. 발치 후 6개월째 Cone beam computed tomography (CBCT) 촬 영결과 임플란트 식립 예상부위는 상악동 하연에서 치조 정까지 수직적 잔존골이 $1.4 \mathrm{~mm}$ 가량이었고 인접치아 와 접하는 골부분은 $1-2 \mathrm{~mm}$ 더 존재하였으며 치조정 부에 피질골이 거의 존재하지 않는 형태로 type 4 골질이
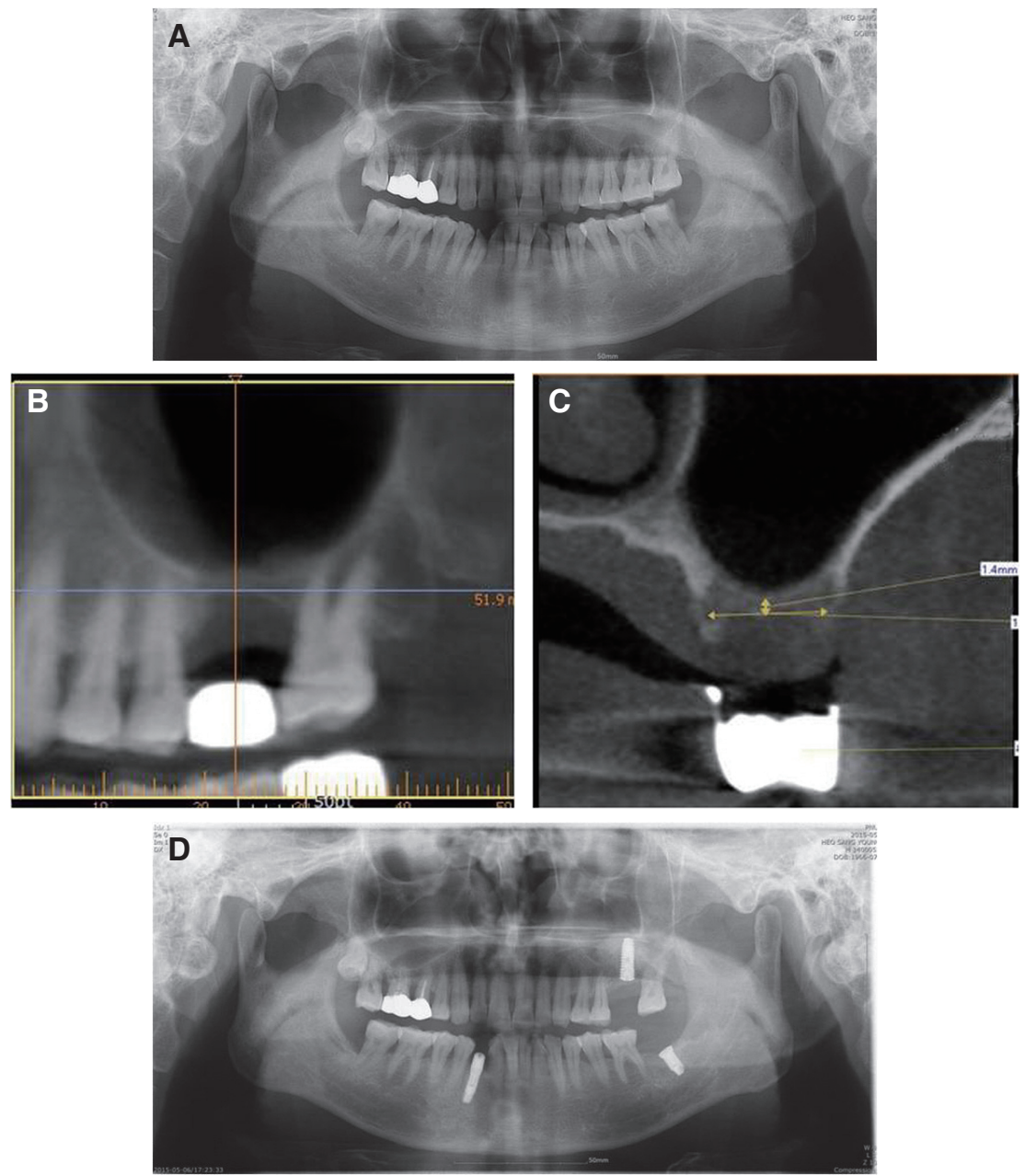

Fig. 1. Radiographic findings of the $1^{\text {st }}$ case. Left maxillary first molar was hopeless due to severe periodontitis (A). Residual bone height was $1.4 \mathrm{~mm}$ and bone quality was very poor on \#26 site (B and C). Panorama view after \#26 implantation (D). 

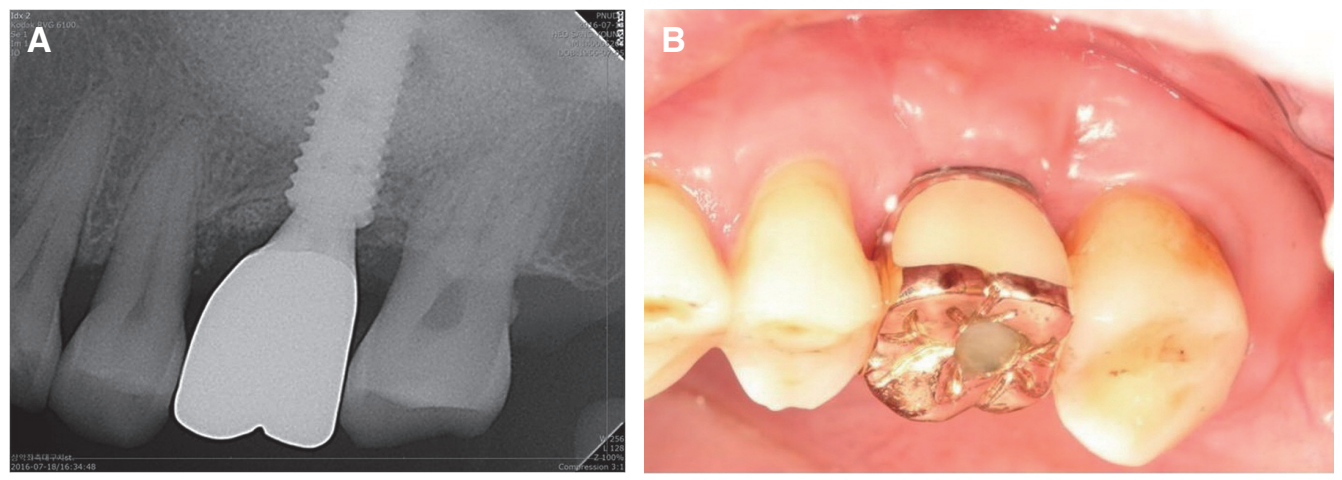

Fig. 2. Radiographic and clinical findings one year after \#26i final prosthesis delivery. Marginal bone and augmented bone level was stable (A) and soft tissue was healthy (B).

었다(Fig. 1B, 1C). 골질과 골량이 불량한 조건임에도 최 소침습적으로 수술을 하기 위해 치조정 접근을 이용하 는 상악동 골이식술을 시행하고 동시에 임플란트를 식립 하기로 하였다. 치조정 중앙에 수평절개를 주고 CAS kit (Crestal approach sinus kit, Osstem, Seoul, Korea)를 이 용하여 상악동저를 거상한 후 형성한 공간내로 이종골 이식재(Bio-Oss, Geistlich, Wolhusen, Swiss)를 이용하 여 골이식을 하였다. 최종 드릴은 3.3 직경의 CAS drill을 이용하였고, 형성한 구멍으로 임플란트 식립시 치조정 상방 $1 \mathrm{~mm}$ 로 위치시켜 이종골 이식재와 흡수성 차폐막 (Bio-Gide, Geistlich)을 이용하여 수직골 증대술도 시행 하였다(Fig. 1D). 직경 $5 \mathrm{~mm}$, 길이 $13 \mathrm{~mm}$ 의 SLA 표면을 가지는 내부 연결형 임플란트(TS III SA, Osstem, Seoul, Korea)를 식립하였고 초기 고정력은 $15 \mathrm{~N}$ 이었다. 합병 증 없이 치유는 잘 이루어졌고 7개월 후 2차 수술 시행하 였을 때 Implant stability quotient (ISQ)는 85였다. 5개 월후 최종 보철물이 장착되고 현재 보철물 장착 후 1 년 경과하였다. 임플란트 주변 연조직뿐만 아니라 방사선상 에서 이식골은 안정적으로 유지되고 있으며 환자는 불편 감 없이 잘 사용하고 있다(Fig. 2).

\section{증례 2}

상악 구치부의 상실을 주소로 내원한 57세 여성 환자 이다. 하악 좌측 구치부가 제 1 대구치까지 잔존하여 상악 좌측 구치부도 제 1 대구치만 수복하기로 하였다. 상악 좌 측 제1대구치(\#26) 부위 CBCT 촬영 결과 type 2 골질로, 과도한 상악동 함기화와 수직골 흡수로 인해 상악동 하 연에서 치조정까지 높이가 $2.2 \mathrm{~mm}$ 였고 수평적 골흡수도 심한 상태로 상악동내 점막 비후가 관찰되었다(Fig. $3 \mathrm{~A}$, $3 \mathrm{~B})$. 술전에 상악동염과 같은 임상 증상은 관찰되지 않 아서 특별한 전처치 없이 진행하였다. 치조제 절개 후 치 조정 접근을 이용하는 상악동 골이식술과 동시에 임플 란트를 식립하였다. CAS kit와 이종골 이식재(Bio-Oss, Geistlich)를 이용하여 상악동 골이식술을 시행하고 직경 $5 \mathrm{~mm}$, 길이 $13 \mathrm{~mm}$ 의 SLA 표면을 가지는 내부 연결형 임플란트(TS III SA, Osstem)를 식립하였다(Fig. 3C). 최 종 드릴은 3.1 직경의 CAS drill을 이용하였고 초기 고정 력은 $37 \mathrm{~N}$ 이었다. 합병증 없이 치유는 이루어졌고 6개월 후 2 차 수술시 ISQ는 85 였다. 2개월 후 최종 보철물이 장 착되고 현재 보철물 장착 후 1 년 6 개월 경과하였다. 방사 선상에서 이식골은 안정적으로 유지되고 있으며 임플란 트 주변 골흡수 없이 건강하게 유지되고 있다(Fig. 3D). 

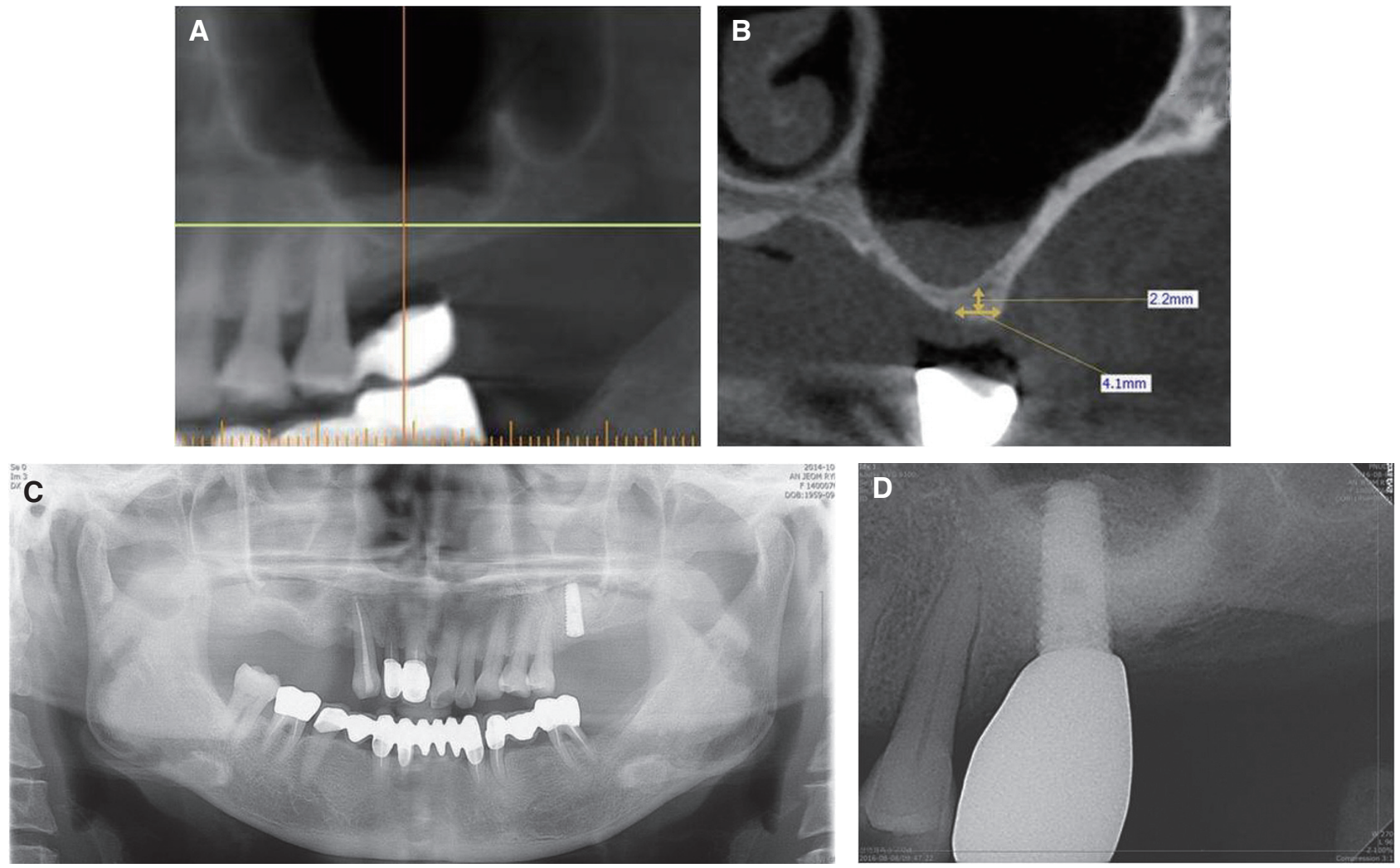

Fig. 3. Radiographic findings of the $2^{\text {nd }}$ case. Residual bone height was $2.2 \mathrm{~mm}$ and schneiderian membrane was thicknening (A and B). Panorama view after \#26 implantation (C). Marginal bone and augmented bone level was stable 1.5 year after final prosthesis delivery (D).

\section{증례 3}

상악 좌측 견치와 제 2 소구치의 상실을 주소로 내원 한 50세 여성 환자이다. 견치 부위는 잔존골이 충분하여 골 이식없이 통상적인 방법으로 임플란트를 식립하였으 나 제2소구치 부위는 $\mathrm{CBCT}$ 촬영 결과 type 3 골질로 상 악동의 과도한 함기화로 수직적 잔존골이 $2.9 \mathrm{~mm}$ 였다 (Fig. 4A, 4B). 치조제 절개 후 치조정 접근을 이용하는 상악동 골이식술과 동시에 임플란트를 식립하였다. CAS kit와 이종골 이식재(Bio-Oss, Geistlich)를 이용하여 상 악동 골이식술을 시행하고 직경 $4 \mathrm{~mm}$, 길이 $13 \mathrm{~mm}$ 의 SLA 표면을 가지는 내부 연결형 임플란트(TS III SA, Osstem)를 식립하였다(Fig. 4C). 최종 드릴은 2.8 CAS drill을 이용하였고 초기 고정력은 $20 \mathrm{~N}$ 이었다. 합병증 없이 치유는 이루어졌고 6 개월 후 2차 수술시 ISQ는 74 였다. 3 개월 후 최종 보철물이 장착되고 현재 보철물 장 착 후 1 년 경과하였다. 방사선상에서 상악동 내 이식골 과 임플란트 변연골은 흡수없이 안정적으로 유지되며 새
롭게 형성된 상악동 하연이 뚜렷히 관찰된다(Fig. $5 \mathrm{~A}$ ). 임 플란트 주변 연조직도 염증없이 건강하게 유지되고 있다 (Fig. 5B).

\section{고찰}

수직적 골 흡수가 심한 상악 구치부에서 임플란트를 식립하기 위해 치조정 접근법을 이용하여 상악동 골이식 을 하는 방법은 측방접근법에 비해 덜 침습적이고 합병 증이 적다고 알려져 있음에도 불구하고 1 회에 상악동저 거상 가능한 양이 제한되어 있다고 알려져 있어 ${ }^{2}$ 심하게 위축된 부위에서는 널리 사용되지 못하였다. 그러나 본 세 가지 증례에서는 잔존하는 수직골이 $3 \mathrm{~mm}$ 이하로 매 우 위축되어 있는 경우에서도 치조정 접근법을 통해 상 악동저 거상 후 골이식을 시행하고 동시에 $13 \mathrm{~mm}$ 길이 의 임플란트를 식립하였다. 이들 증례에서 시술시 어려운 점은 상악동 막의 천공없이 1 회에 $10 \mathrm{~mm}$ 이상의 많은 양의 상악동저를 거상하고 골이식술을 시행해야 하는 것 

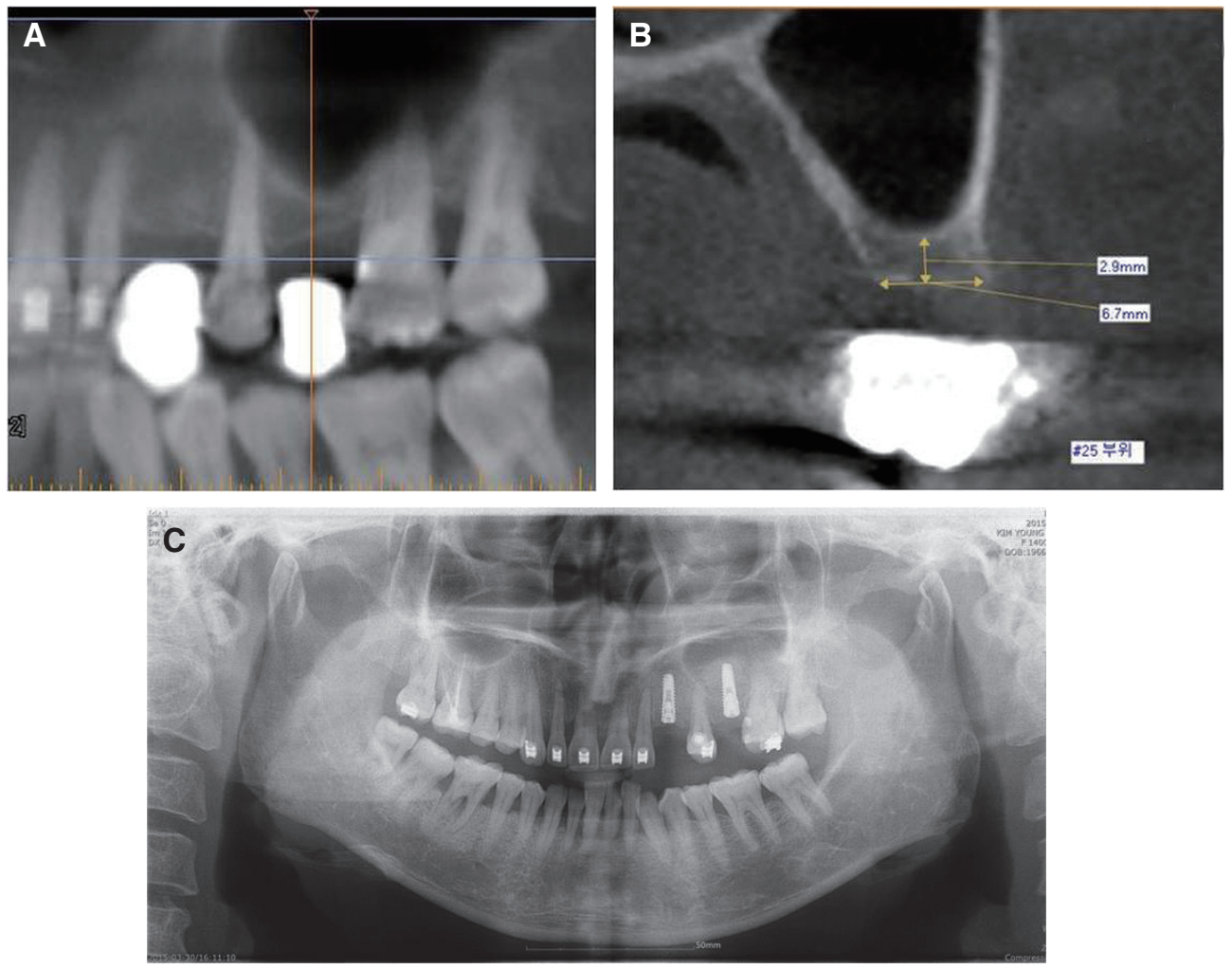

Fig. 4. Radiographic findings of the $3^{\text {rd }}$ case. Residual bone height was $2.9 \mathrm{~mm}$ and poor bone quality was observed (A and B). Panorama view after \#23 and \#25 implantation (C).
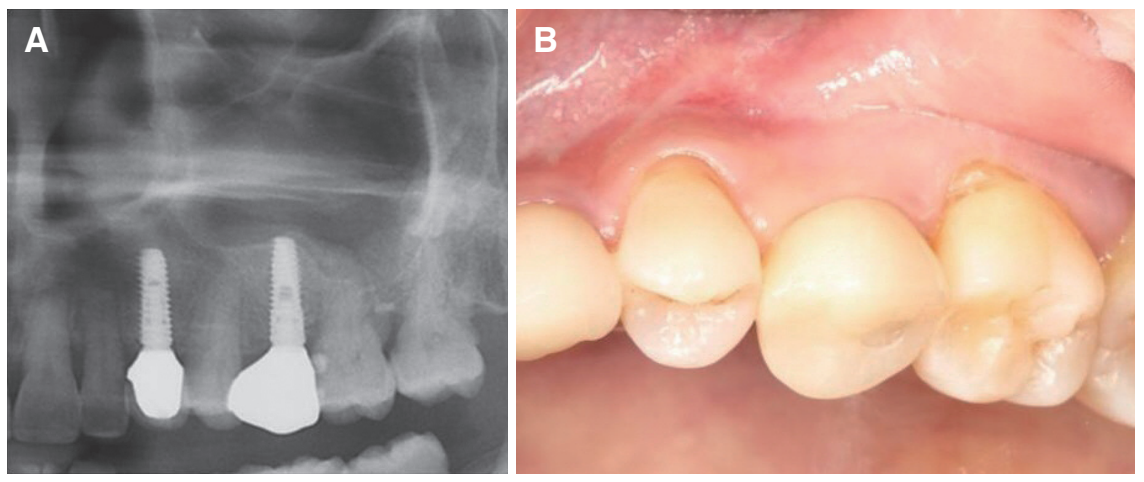

Fig. 5. Radiographic and clinical findings one year after \#25i final prosthesis delivery. Marginal bone and augmented bone level was stable (A) and soft tissue was healthy (B).

과 좋지 않은 골질을 가지는 적은 양의 잔존골에서도 적 절한 임플란트 초기 고정을 획득하는 것이다.

치조정 접근법을 이용하는 상악동 골이식술은 측방접 근법에 비해 최소한의 점막 박리, 상악동 측벽 보존, 술후 불편감이나 상악동 점막 천공과 같은 합병증 감소 등의 이점이 있다. ${ }^{5}$ 초기에 치조정 접근법은 1994년 Summers 에 의해 제안된 골절도(osteotome)를 이용한 상악동 골 이식 술법으로 드릴로 골을 삭제하는 것이 아니라 골절 도를 수직방향으로 두드림으로써 상악동 하연의 피질골
의 greenstick fracture 후 상악동저를 거상시키는 방법이 었다. 이 술기는 임플란트를 식립할 구멍 주변 골을 응축 시켜서 골밀도를 높이는 장점이 있었다. ${ }^{6}$ 그러나 mallet을 이용하여 골절도를 두드릴 때 기계적인 충격을 가함으로 써 환자에게 불쾌감, 현기증, 두통 드물지만 이석증과 같 은 부작용이 발생하는 경우가 있다. 최근에는 상악동 골 이식을 위한 다양한 수술 도구들의 발달로 기존의 골절 도법의 장점을 살리고 단점을 극복하는 수술이 가능하게 되었다. ${ }^{4,8}$ 
본 증례들에서 사용한 수술 도구는 상악동막을 안전 하게 거상하는 전용 드릴, 수압거상 기구, bone spreader 와 condenser로 구성된다. 상악동막과 접하고 있는 피질 골을 함께 거상하는 전용 드릴은 잔존골이 $3 \mathrm{~mm}$ 미만 이었으므로 50 - $100 \mathrm{rpm}$ 정도로 매우 저속으로 설정하 여 술자가 상악동막이 들어올려짐을 느낄 수 있었다. 수 압거상 기구에 $1.5 \mathrm{cc}$ 식염수를 주입한 뒤 막을 전반적으 로 피질골에서 분리시키고 골이식재를 충전하였다. 골이 식재 충전시 $25 \mathrm{rpm}$ 으로 설정한 bone spreader를 회전 시켜 충전한 골을 넓게 분산시켰고, 골 충전과 분산을 반 복 시행함으로써 상악동막에 긴장이 가지 않도록 하였 다. 상악동막의 천공은 $7.3 \mathrm{~N} / \mathrm{mm}^{2}$ 이상의 장력이 적용 될 때 발생되는 경향이 있고 $1.5 \mathrm{cc}$ syringe의 식염수를 적 용했을 때 발생되는 장력은 $0.2 \mathrm{~N} / \mathrm{mm}^{2}$ 이하이므로 ${ }^{8}$ 막 천공의 위험성은 매우 낮았다. 또한 골 충전과 분산의 반 복 시행으로 막의 긴장을 줄이고 dome-shape으로 상악 동 골이식이 가능하였다. 세 증례 모두 $13 \mathrm{~mm}$ 길이의 임 플란트를 식립함으로써 수직적으로 $10 \mathrm{~mm}$ 가량의 상악 동 골이식을 이루었다.

최근 논문들에서는 전통적인 개념과는 달리 잔존골이 $4 \mathrm{~mm}$ 미만이더라도 치조정 접근법을 이용하여 긴 임플 란트를 식립하는 것이 믿을만하다고 하였다. ${ }^{8-10}$ 그러나 이러한 경우 적절한 초기 고정을 얻어 동시에 임플란트 식립을 가능하게 하는 것은 술자의 경험과 술기에 달려 있을 것이다. ${ }^{9}$ 잔존 수직골이 적을수록 또한 골질이 나쁠 수록 골 삭제는 최소한으로 하며 bone condenser를 이 용하여 주변 골을 응축시켜 안정적인 초기 고정을 달성 할 수 있다. 두 번째 증례에서는 첫 번째 증례보다 잔존 하는 골에 피질골 성분이 많았고 최종 삭제 드릴을 더 적 은 크기의 것을 사용하여 수직적 잔존골이 $2.2 \mathrm{~mm}$ 였음 에도 불구하고 초기 고정력이 $37 \mathrm{~N}$ 이었다. 임플란트 길 이가 길수록 초기 고정력을 증가시킬수 있으므로 ${ }^{11}$ 세 증 례 모두 $13 \mathrm{~mm}$ 길이의 임플란트를 식립하여 안정적인 초기 고정을 달성 할 수 있었다.

최소 침습적 수술 접근이라는 장점에도 불구하고 치 조정 접근은 맹검 기법이라는 한계가 있다. ${ }^{12}$ 측방접근법 과 같이 상악동 막을 노출시켜서 직접 거상하는 것이 아 니므로 막천공 여부에 대한 불확실성이 존재한다. 그럼 에도 불구하고 지금까지 보고된 결과로는 치조정 접근 법 후에 상악동 막 천공 비율은 $0-21.4 \%$ 로 평균 3.8\%, 술 후 이식재 감염은 $0.8 \%{ }^{13,14}$ 측방접근법 후 막 천공 0 $58.3 \%$ 로 평균 $19.5 \%$ 와 이식재 감염 $2.9 \%{ }^{14}$ 와 비교 하였
을 때 술 후 합병증 발생 가능성이 낮다.

치조정 접근법을 이용한 상악동 골이식 후 장기간 임 플란트의 성공율이 측방접근법을 시행했을 때 보다 높 다고 알려져 있다. ${ }^{15}$ 이러한 결과 차이는 치조정 접근법의 경우 대부분 잔존골이 $6 \mathrm{~mm}$ 이상인 경우였기 때문에 실 패 가능성이 낮아졌다고 분석하였다. 그러나 최근 보고 에 따르면 잔존골이 $3 \mathrm{~mm}$ 이하인 경우에 치조정 접근법 을 이용한 상악동 골이식 및 임플란트 식립 후 평균 10년 가량 경과 관찰한 결과 46명의 환자 66개의 임플란트에 서 $95 \%$ 생존율을 보고하였다. ${ }^{5}$ 수직적으로 심한 골흡수 가 있는 구치부에서 덜 침습적이고 술 후 합병증 발생 가 능성이 낮은 수술법인 치조정 접근법을 이용하여 상악동 골이식술과 임플란트 동시식립을 하는 것은 환자 중심 치료계획 수립과 최소 침습적 시술이라는 측면에서 의미 가 있으나 장기간 임플란트 성공율과 관련해서는 좀 더 많은 연구가 진행되어야 할 것이다.

\section{결론}

본 증례들에서는 잔존 수직골 $3 \mathrm{~mm}$ 미만으로 심하게 위축된 상악 구치부에서 치조정 접근법을 이용하여 10 $\mathrm{mm}$ 가량의 상악동저 거상 및 골 이식술을 시행함과 동 시에 임플란트를 식립하였다. 합병증 없이 보철치료까지 마무리 한 후 단기간 관찰한 결과 임플란트 주변 경, 연 조직 모두 건강하고 환자도 불편감 없이 만족하였다. 적 절한 치료 방법으로 제안되나 장기간의 임플란트 성공율 은 관찰해보아야 할 것으로 사료된다.

\section{Acknowledgements}

본 연구는 2016년도 부산대학교 치과병원 임상연구비 지원으로 이루어졌음.

\section{ORCID}

Hyun-Joo Kim http://orcid.org/0000-0001-7553-6289 Eun-Young Kwon http://orcid.org/0000-0001-95550360

Jeomil Choi http://orcid.org/0000-0002-7491-6711

Ju-Youn Lee http://orcid.org/0000-0002-0772-033X Ji-Young Joo http://orcid.org/0000-0002-4050-5797 


\section{References}

1. Woo I, Le BT. Maxillary sinus floor elevation: review of anatomy and two techniques. Implant Dent 2004;13:28-32.

2. Block MS. Improvements in the crestal osteotome approach have decreased the need for the lateral window approach to augment the maxilla. J Oral Maxillofac Surg 2016;74:2169-81.

3. Esposito M, Felice P, Worthington HV. Interventions for replacing missing teeth: augmentation procedures of the maxillary sinus. Cochrane Database Syst Rev 2014;5;CD008397.

4. Tallarico M, Meloni SM, Xhanari E, Pisano M, Cochran DL. Minimally invasive sinus augmentation procedure using a dedicated hydraulic sinus lift implant device: a prospective case series study on clinical, radiologic, and patient-centered outcomes. Int J Periodontics Restorative Dent 2017;37:125-35.

5. Bruschi GB, Crespi R, Capparè P, Gherlone E. Transcrestal sinus floor elevation: a retrospective study of 46 patients up to 16 years. Clin Implant Dent Relat Res 2012;14:759-67.

6. Pjetursson BE, Ignjatovic D, Matuliene G, Brägger U, Schmidlin K, Lang NP. Transalveolar maxillary sinus floor elevation using osteotomes with or without grafting material. Part II: radiographic tissue remodeling. Clin Oral Implants Res 2009;20:67783.

7. Giannini S, Signorini L, Bonanome L, Severino M, Corpaci F, Cielo A. Benign paroxysmal positional vertigo (BPPV): it may occur after dental implantology. A mini topical review. Eur Rev Med Pharmacol Sci 2015;19:3543-7.

8. Better H, Slavescu D, Barbu H, Cochran DL, Chaushu G. Minimally invasive sinus lift implant device: a multicenter safety and efficacy trial preliminary results. Clin Implant Dent Relat Res 2014;16: 520-6.

9. Kher U, Ioannou AL, Kumar T, Siormpas K, Mitsias ME, Mazor Z, Kotsakis GA. A clinical and radiographic case series of implants placed with the simplified minimally invasive antral membrane elevation technique in the posterior maxilla. J Craniomaxillofac Surg 2014;42:1942-7.

10. Mazor Z, Kfir E, Lorean A, Mijiritsky E, Horowitz RA. Flapless approach to maxillary sinus augmentation using minimally invasive antral membrane balloon elevation. Implant Dent 2011;20:434-8.

11. Bataineh AB, Al-Dakes AM. The influence of length of implant on primary stability: an in vitro study using resonance frequency analysis. J Clin Exp Dent 2017;9:e1-e6.

12. Tan WC, Lang NP, Zwahlen M, Pjetursson BE. A systematic review of the success of sinus floor elevation and survival of implants inserted in combination with sinus floor elevation. Part II: transalveolar technique. J Clin Periodontol 2008;35:24154.

13. Pjetursson BE, Lang NP. Sinus floor elevation utilizing the transalveolar approach. Periodontol 2000 2014;66:59-71.

14. Pjetursson BE, Tan WC, Zwahlen M, Lang NP. A systematic review of the success of sinus floor elevation and survival of implants inserted in combination with sinus floor elevation. J Clin Periodontol 2008;35:216-40.

15. Lundgren S, Cricchio G, Hallman M, Jungner M, Rasmusson L, Sennerby L. Sinus floor elevation procedures to enable implant placement and integration: techniques, biological aspects and clinical outcomes. Periodontol 2000 2017;73:103-120. 


\section{골 흡수가 심한 상악 구치부에서 치조정 접근법을 이용하여 상악동 골이식술 동시 임플란트 식립}

김현주, 권은영, 최점일, 이주연, 주지영*

부산대학교 치의학전문대학원 치주과

상악 구치부는 치조제 골 흡수와 상악동 함기화로 인해 가용골의 양은 제한되고 골질도 좋지 않은 경우가 대부분으로 상악동저의 거상 후 가용골의 증대와 취약한 골에서 임플란트의 견고한 초기 고정을 획득하는 것이 중요하다. 심하게 위 축된 치조제의 경우 임플란트의 적절한 초기 고정 획득을 위해 측방접근법을 통한 상악동 골이식술이나 지연 임플란트 식립법이 추천되나 본 연구에서는 수직적 잔존골 높이가 $3 \mathrm{~mm}$ 이하인 상악 구치부 세 증례를 통해 수직 골 소실이 심한 상악 구치부에서 전통적인 개념과는 달리 최소침습적 수술법으로 치조정 접근을 통한 상악동 골이식과 동시에 임플란트 식립을 시행하여 합병증 없이 충분한 길이의 임플란트 식립이 가능함을 제안한다.

(구강회복응용과학지 2017;33(1):47-54)

주요어: 치과용임플란트; 상악동; 치조골이식술; 구치부

*교신저자: 주지영

(50612)경남 양산시 물금읍 범어리 금오로 20 부산대학교 치의학전문대학원 치주과

Tel: 055-360-5203 | Fax: 055-360-5194 || E-mail: joojy@pusan.ac. kr

|접수일: 2017년 1월 20일 | 수정일: 2017년 2월 14일 | 채택일: 2017년 2월 26일 